\title{
SYNTHESIS AND ANTIMICROBIAL ACTIVITY OF SOME AMIDE DERIVATIVES
}

\author{
Asif Husain and Mohd Rashid \\ Department of Pharmaceutical Chemistry, Faculty of Pharmacy \\ Hamdard University, New Delhi-110062, INDIA \\ Email:drasifhusain@yahoo.com
}

\begin{abstract}
A series of amide derivatives has been synthesized through one-pot method by condensing appropriate 4-oxo-4-(4-substituted phenyl)butanoic acid moiety with isoniazid. The amides have been evaluated for their antimicrobial activity (Minimum Inhibitory Concentration MIC) against Bacillus subtilis, Klebsiella pneumoniae and Candida albicans. One compound, $2 b$, was found to have significant antimicrobial activity.
\end{abstract}

\section{RESUMO}

Uma série de derivados de amidas foi sintetizada condensando o ácido 4-oxo-4-(4fenil substituído) butanóico apropriado com isoniazida.. A atividade antimicrobial (Concentração Inibitória Mínima - CIM) foi avaliada com Bacillus subtilis, Klebsiella pneumoniae e Candida albicans. O composto $2 b$ exibiu atividade antimicrobial significante.

\section{INTRODUCTION}

Over the past few decades the bacterial resistance to antibiotics has become one of the most important problems of infections treatment (1). Searching for new compounds, which would combine a non specific activity against a broad spectrum of bacteria and low toxicity seems to be a promising way to overcome that problem. Isoniazid is an important antibacterial drug and to increase its usefulness various derivatives have been synthesized with encouraging results (2).

VISIT OUR SITE: http://www.sbjchem.he.com.br 


\section{SOUTH. BRAZ. J. CHEM。, Vol.18, No. 18, 2010 \\ Synthesis and Antimicrobial Activity of Some Amide Derivatives}

30

On the other hand, the derivatives of 4-oxo-4-(substituted phenyl)butanoic acid also show potential antimicrobial activities $(3,4)$. In view of these points and in continuation of our work on novel amides (1-3), it was considered worthwhile to study various amide derivatives of isoniazid with 4-oxo-4-(substituted phenyl)butanoic acids with a view to obtain potential antimicrobial agents. Therefore, five different 4-oxo-4-(substituted phenyl)butanoic acids were condensed with isoniazid and their structures were established on the basis of elemental analysis, ${ }^{1}$ H NMR and Mass spectral data. These compounds were evaluated for their antimicrobial activities against some selected microbes.

\section{MATERIALS AND METHODS}

\section{Synthesis}

Melting points were determined in open capillary tubes and are uncorrected. ${ }^{1} \mathrm{H}-\mathrm{NMR}$ spectra were recorded on DPX-300 NMR spectrometer. The splitting pattern abbreviations are as follows: $\mathrm{s}$, singlet; $\mathrm{d}$, doublet; $\mathrm{t}$, triplet; $\mathrm{q}$, quartet; $\mathrm{m}$, multiplet. Mass spectra were recorded on a Jeol JMS-D 300 instrument fitted with a JMS 2000 data system at $70 \mathrm{eV}$. Microanalyses of the compounds were found within $\pm 0.4 \%$ of the theoretical values. All solvents were distilled prior use. The progress of the reactions was monitored on silica gel $\mathrm{G}$ plates using iodine vapors as visualizing agent.

Synthesis of 4-oxo-4-(substituted phenyl)butanoic acid (1a-e)

These compounds were synthesized by following the method reported in literature (3). 
SOUTH. BRAZ. J. CHEM., Vol.18, No. 18, 2010

A. Husain and M. Rashid

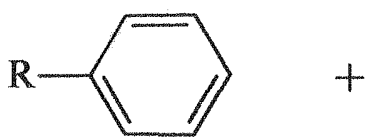<smiles>O=C1CCC(=O)O1</smiles>

Substituted benzene

Succinic anhydride

Anhyd. $\mathrm{AlCl}$<smiles>[R]c1ccc(C(=O)CCC(=O)O)cc1</smiles>

4-Oxo-4-(4-substituted phenyl)butanoic acids ( 1a-e)

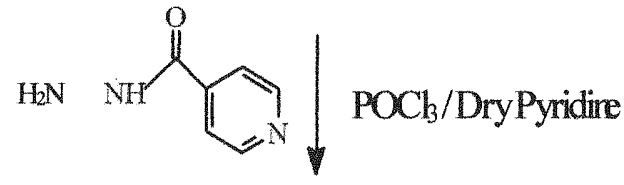<smiles>[R]c1ccc(C(=O)CCC(=O)NNC(C)=O)cc1</smiles>

Scheme 1. Protocol for synthesis of isoniazid amides ( 2 a-e). 


\section{SOUTH. BRAZ. J. CHEM., Vol.18, No. 18, 2010 \\ Synthesis and Antimicrobial Activity of Some Amide Derivatives}

32

\section{General procedure for the synthesis of Isoniazid a mides ( 2 a-e)}

Amides were synthesized by dissolving 4-oxo-4-(substituted phenyl)butanoic acid (1a-e) $(0.001 \mathrm{~mol})$ and isoniazid $(0.001 \mathrm{~mol})$ in minimum quantity of dry pyridine separately. The two solutions were then mixed together and stirred magnetically followed by the addition of phosphorous oxychloride $(0.9 \mathrm{ml})$ drop wise while maintaining the temperature below $5^{\circ}$. The contents were stirred for another half-hour and left overnight. The reaction mixture was then poured into ice cold water and a solid mass, which separated out, was filtered, washed, dried and crystallized from ethanol to give 2a-e (See Table 1).

\section{Antimicrobial activity}

All the newly synthesized compounds were screened for their antibacterial activity against Bacillus subtilis, Klebsiella pneumoniaa and Candida albicans at a concentration of 100 $\mu \mathrm{g} / \mathrm{ml}$ by turbidity method (5). Compounds inhibiting growth of one or more of the above microorganisms were further tested for minimum inhibitory concentration (MIC). Solvent (DMF) and growth controls were kept. Minimum inhibitory concentrations (MICs) were determined by broth dilution technique. The nutrient broth, which contained logarithmic serially two fold diluted amount of test compound and controls were inoculated with approximately $5 \times 10^{5}$ c.f.u. of actively dividing bacteria cells. The cultures were incubated for $24 \mathrm{~h}$ at $37^{\circ} \mathrm{C}$ and the growth was monitored visually and spectrophotometrically. Ciprofloxacin and griseofulvin were used as standard drugs for comparison. The lowest concentration (highest dilution) required to arrest the growth of microbes was regarded as $M I C$. 


\section{SOUTH. BRAZ.J. CHEM., Vol.18, No. 18, 2010}

\section{A. Husain and M. Rashid}

\section{RESULTS AND DISCUSSION}

\section{Synthesis}

The synthesis of the title compounds was performed in a one-pot reaction method and is presented in Scheme 1. In the initial step, 4-oxo-4-(substituted phenyl)butanoic acid (1a-e) were prepared by condensing substituted benzenes with succinic anhydride in presence of anhydrous aluminium chloride following Friedel-Craft's acylation reaction conditions (3). The desired amides (2a-e) were synthesized by reacting 4-oxo-4-(substituted phenyl)butanoic acid (1a-e) with isoniazid in dry pyridine in presence of phosphorous oxychloride as condensing agent and obtained in appreciable yields (50-61\%). The purity of the compounds was controlled by TLC in solvent system toluene:ethyl acetate:formic acid $(5: 4: 1)$. Spectral data and microanalysis data were in agreement with the proposed structures. The physical and analytical data are recorded in Table-1.

The nuclear magnetic resonance spectra $\left({ }^{1} \mathrm{H}\right.$ NMR; $\delta$ ppm) showed two triplets at around $\delta 2.8 \& 3.3\left(-\mathrm{CH}_{2}-\mathrm{CH}_{2}-\right)$; signals in the region $\delta 7.5-8.6$ (aryl protons). The mass spectra showed molecular ion peaks in reasonable intensities supporting the structure. There was splitting of Ar$\mathrm{COCH}_{2} \mathrm{CH}_{2}-\mathrm{CON}$-bond resulting in formation of $\mathrm{Ar}-\mathrm{COCH}_{2} \mathrm{CH}_{2}-\mathrm{C} \equiv \mathrm{O}^{+}$(fragment-1) or [Ar$\mathrm{COCH}_{2} \mathrm{CH}=\mathrm{C}=\mathrm{O}^{+}$(fragment-2) and/or $\mathrm{C}_{5} \mathrm{H}_{4} \mathrm{~N}-\mathrm{C} \equiv \mathrm{O}^{+}$. These fragments provided important clue for successful formation of the product. Fragment-1/2 further splitted to $\mathrm{Ar}-\mathrm{C} \equiv \mathrm{O}^{+}$and to $\mathrm{Ar}^{+}$and then to $\mathrm{C}_{6} \mathrm{H}_{5}^{+}(\mathrm{m} / \mathrm{z}=77)$. 


\section{SOUTH. BRAZ. J. CHEM., Vol.18, No. 18, 2010 \\ Synthesis and Antimicrobial Activity of Some Amide Derivatives}

Table 1. Physical and spectral data of the amide derivatives of isoniazid (2a-e).

\begin{tabular}{|c|c|c|c|c|c|c|c|}
\hline \multirow[t]{2}{*}{ Compd } & \multirow[t]{2}{*}{$\mathrm{R}$} & \multirow{2}{*}{$\begin{array}{l}\text { M.p.; } \\
\text { Yield } \\
(\%)\end{array}$} & \multirow{2}{*}{$\begin{array}{l}\text { Mol. formula; } \\
\text { Mass spectral } \\
\text { data }(\mathrm{m} / \mathrm{z})\end{array}$} & \multirow{2}{*}{$\begin{array}{c}\text { 'H NMR spectral data } \\
(\delta \mathrm{ppm})\end{array}$} & \multicolumn{3}{|c|}{ Antimicrobial activity $(M / C)$} \\
\hline & & & & & $\begin{array}{c}\text { B. } \\
\text { subtilis }\end{array}$ & $\begin{array}{c}K \\
\text { pneumoniae }\end{array}$ & $\begin{array}{c}C . \\
\text { albicans }\end{array}$ \\
\hline $2 a$ & $\mathrm{H}-$ & $\begin{array}{l}128- \\
130 \\
58\end{array}$ & $\begin{array}{c}\mathrm{C}_{16} \mathrm{H}_{15} \mathrm{~N}_{3} \mathrm{O}_{3} \\
297\left(\mathrm{M}^{+}\right), 279 \\
160,105,78 \\
77\end{array}$ & $\begin{array}{l}2.77 \text { \& } 3.43 \text { (t, each, } 2 \times- \\
\left.\mathrm{CH}_{2}\right), 7.56(\mathrm{~m}, 3 \mathrm{H}, \mathrm{H}-3,4,5, \\
\text { phenyl ring), } 7.89(\mathrm{~m}, 2 \mathrm{H}, \mathrm{H}- \\
\text { '2,6, phenyl ring), } 8.25 \text { \& } \\
8.73 \text { (d, each, } \mathrm{A}_{2} \mathrm{~B}_{2}, 4 \mathrm{H}, 4- \\
\text { pyridyl ring), } 9.16 \& 9.83(\mathrm{~s}, \\
\text { each, } 2 \mathrm{x}-\mathrm{NH}-\text {-). }\end{array}$ & $>100$ & $>100$ & 50.0 \\
\hline $2 \mathrm{~b}$ & $\mathrm{Cl}-$ & $\begin{array}{l}172- \\
174 \\
55\end{array}$ & $\begin{array}{c}\mathrm{C}_{16} \mathrm{H}_{14} \mathrm{CIN}_{3} \mathrm{O}_{3} \\
331\left(\mathrm{M}^{+}\right), 332 \\
\left(\mathrm{M}^{+}+1\right), 193 \\
139,111,53\end{array}$ & $\begin{array}{l}2.78 \& 3.31 \text { (t, each, } 2 \mathrm{x}- \\
\left.\mathrm{CH}_{2}-\mathrm{CH}_{2^{-}}\right), 7.43 \& 7.67(\mathrm{~d}, \\
\text { each, } \mathrm{A}_{2} \mathrm{~B}_{2}, 4 \mathrm{H}, \quad \text {-chloro } \\
\text { phenyl ring), 8.06 \& } 8.77 \text { (d, } \\
\text { each, } \mathrm{A}_{2} \mathrm{~B}_{2}, 4 \mathrm{H}, 4 \text {-pyridyl } \\
\text { ring), } 9.28 \& 9.65 \text { (s, each, } \\
2 \mathrm{x}=\mathrm{NH}-\text { ). }\end{array}$ & 12.5 & 25.0 & 12.5 \\
\hline $2 \mathfrak{c}$ & $\mathrm{CH}_{3-}$ & $\begin{array}{l}140- \\
142 \\
50\end{array}$ & $\begin{array}{c}\mathrm{C}_{17} \mathrm{H}_{17} \mathrm{~N}_{3} \mathrm{O}_{3} \\
311\left(\mathrm{M}^{+}\right), 119 \\
91,78,77\end{array}$ & $\begin{array}{l}2.39\left(\mathrm{~s}, 3 \mathrm{H},-\mathrm{CH}_{3}\right), 2.63 \& \\
3.26\left(\mathrm{t}, \text { each, } 2 \mathrm{x}-\mathrm{CH}_{2^{+}}\right), 7.28 \\
\& 7.88\left(\mathrm{~d}, \text { each, } \mathrm{A}_{2} \mathrm{~B}_{2}, 4 \mathrm{H}, p-\right. \\
\text { 'tolyl ring), } 7.81 \& 8.79 \text { (d, } \\
\text { each, } \mathrm{A}_{2} \mathrm{~B}_{2}, 4 \mathrm{H}, 4 \text {-pyridyl } \\
\text { ring), 9.11\& } 8.36 \text { (s, each, } \\
2 \mathrm{x}-\mathrm{NH}-) \text {. }\end{array}$ & 25.0 & 50.0 & 25.0 \\
\hline 2d & $\mathrm{C}_{2} \mathrm{H}_{5}-$ & $\begin{array}{l}156- \\
158 \\
56\end{array}$ & $\begin{array}{c}\mathrm{C}_{18} \mathrm{H}_{19} \mathrm{~N}_{3} \mathrm{O}_{3} \\
325\left(\mathrm{M}^{+}\right), 307, \\
133,105,91 \\
77\end{array}$ & $\begin{array}{l}1.25\left(\mathrm{t}, 3 \mathrm{H},-\mathrm{CH}_{3}\right), 2.68 \text { (q, } \\
\left.2 \mathrm{H},-\mathrm{CH}_{2}\right), 2.73 \text { \& } 3.34(\mathrm{t}, \\
\left.\text { each, } 2 \mathrm{x}-\mathrm{CH}_{2}\right), 7.29 \& 7.83 \\
\text { (d, each, } \mathrm{A}_{2} \mathrm{~B}_{2}, 4 \mathrm{H}, p \text {-ethyl } \\
\text { phenyl ring), } 7.81 \& 8.71 \text { (d, } \\
\text { each, } \mathrm{A}_{2} \mathrm{~B}_{2}, 4 \mathrm{H}, 4 \text {-pyridyl } \\
\text { ring), } 9.08 \& 9.19 \text { (s, each, } \\
2 \mathrm{x}-\mathrm{NH}) \text { ). }\end{array}$ & $>100$ & $>100$ & $>100$ \\
\hline $2 e$ & $\mathrm{CH}_{3} \mathrm{O}-$ & $\begin{array}{l}148 \\
150 \\
61\end{array}$ & $\begin{array}{c}\mathrm{C}_{17} \mathrm{H}_{17} \mathrm{~N}_{3} \mathrm{O}_{4} \\
327\left(\mathrm{M}^{+}\right), 191, \\
189,135,78\end{array}$ & $\begin{array}{l}3.82\left(\mathrm{~s}, 3 \mathrm{H},-\mathrm{OCH}_{3}\right), 2.78 \& \\
3.30\left(\mathrm{t} \text {, each, } 2 \mathrm{x}-\mathrm{CH}_{2}-\right), 6.96 \\
\& 7.56\left(\mathrm{~d} \text {, each, } \mathrm{A}_{2} \mathrm{~B}_{2}, 4 \mathrm{H}, p-\right. \\
\text { methoxy phenyl ring), } 7.91 \\
\& 8.83\left(\mathrm{~d} \text {, each, } 4 \mathrm{H}, \mathrm{A}_{2} \mathrm{~B}_{2}, 4-\right. \\
\text { pyridyl ring), } 9.23 \text { \& } 10.11 \\
\text { (s, each, } 2 \mathrm{x}-\mathrm{NH}-) \text {. }\end{array}$ & 50.0 & $>100$ & 25.0 \\
\hline Stand & dard $-1^{\dagger}$ & & & & 6.25 & 6.25 & $\mathrm{nt}$ \\
\hline Stand & dard $-2^{\dagger}$ & & & & $\mathrm{nt}$ & $\mathrm{nt}$ & 6.25 \\
\hline Contr & & & & & - & - & - \\
\hline
\end{tabular}

$n t=$ not tested; Standard-1 = Ciprofloxacin, Standard-2 = Griseofulvin; $M / C=$ minimum inhibitory concentration 
SOUTH. BRAZ. J. CHEM., Vol.18, No. 18, 2010

A. Husain and M. Rashid

The fragment $\mathrm{C}_{5} \mathrm{H}_{4} \mathrm{~N}-\mathrm{C} \equiv \mathrm{O}^{+}$further splitted to $\mathrm{C}_{5} \mathrm{H}_{4} \mathrm{~N}^{+}$. The fragmentation pattern is presented in Chart 1.

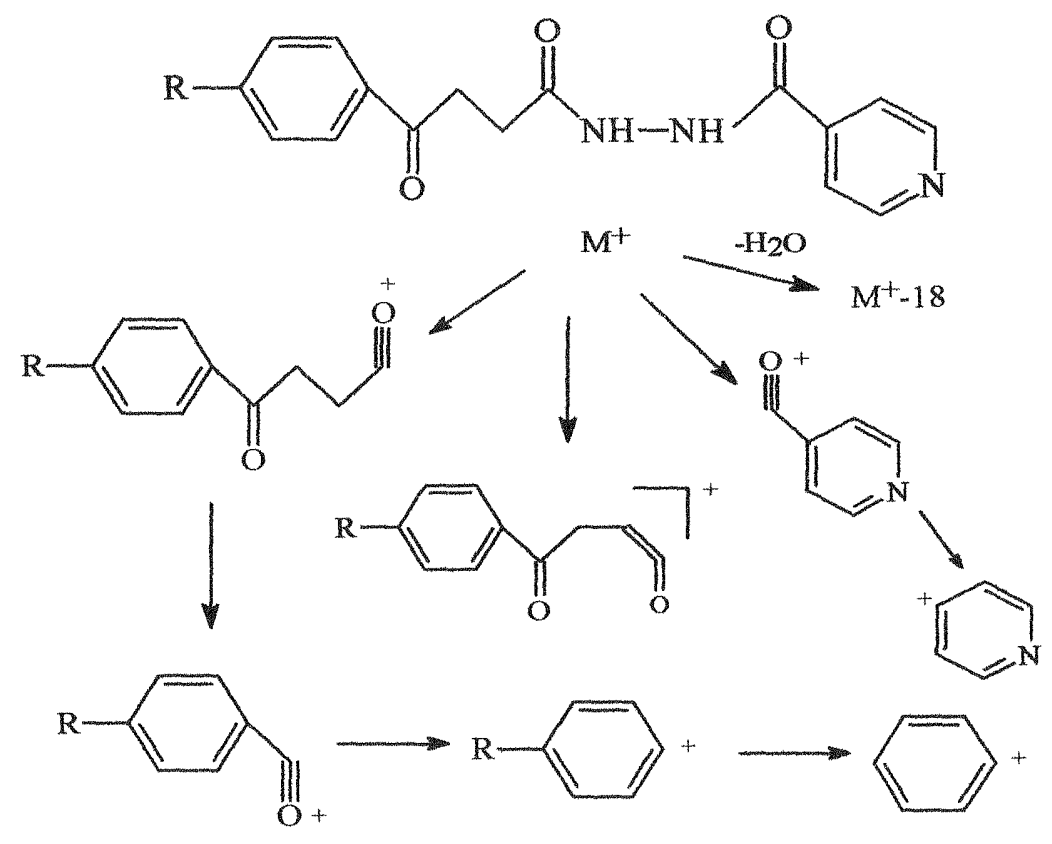

Chart 1. Proposed Mass fragmentation pattern of Amides

\section{Antimicrobial activity}

The antimicrobial activity (minimum inhibitory concentration $-M I C$ ) of the compounds was evaluated against $B$. subtilis, $K$. pneumoniae and C. albicans. Ciprofloxacin (MIC-6.25 $\mu \mathrm{g} / \mathrm{mL})$ and griseofulvin (MIC-6.25 $\mu \mathrm{g} / \mathrm{mL}$ ) were used as standard drugs for comparison. The compounds $\mathbf{2 b}$ showed very good activity against $B$. subtilis and $C$. albicans with $M I C-12.5$ $\mu \mathrm{g} / \mathrm{mL}$ and good activity against $K$. pneumoniae with $M I C-25 \mu \mathrm{g} / \mathrm{mL}$ concentration. Another compound, compounds $\mathbf{2 c}$, showed significant activity against $B$. subtilis and $C$. albicans with $M I C-25.0 \mu \mathrm{g} / \mathrm{mL}$. Rest of the compounds were moderate in their action. From the antibacterial 
SOUTH. BRAZ. J. CHEM., Vol.18, No. 18, 2010

\section{Synthesis and Antimicrobial Activity of Some Amide Derivatives}

results, it was observed that the compound having chloro function ( $2 \mathbf{b}$ ) was most active among the tested compounds (Table 1).

\section{CONCLUSION}

In conclusion, five amide derivatives (2a-e) were successfully synthesized. Among these, one compound $\mathbf{2 b}$ exhibited good activity against $B$. subtilis and $C$. albicans with $M I C-12.5$ $\mu \mathrm{g} / \mathrm{mL}$. These results showed the importance of exploring old drugs to obtain compounds of potential pharmaceutically interest.

Acknowledgement: We are thankful to the Department of Science \& Technology (DST), New Delhi, for the financial support.

\section{REFERENCES}

1. Khan, M. S. Y., Husain A., Hasan S. M., Akhter M., Scientia Pharmaceutica, 70, 277, 2002 .

2. Hearn M. J., Cynamon M. H., J. Antimicrob. Chemother. 53, 185, 2004.

3. Husain A., Khan M.S.Y., Proceedings. $19^{\text {th }}$ American Peptide Symposium, p. 567, San Diego, California, USA, 2005.

4. Husain A., Sarafroz M., Ahuja P., Acta Poloniae Pharmaceutica (Drug Research), 65, 527, 2008.

5. Cruickshank R., Dugid J. P., Marmion D. P., Swain R. H. A., Medical Microbiology, vol. 2, p. 2, Churchill-Livingstone, Edinburge, London, 1975.

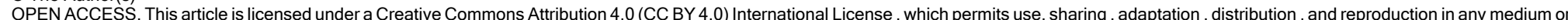

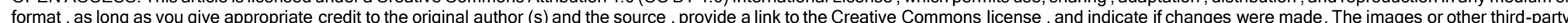

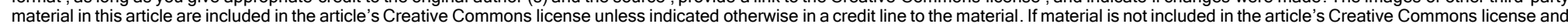

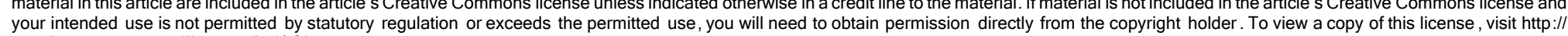

